\title{
A ROMAN FORTIFIED HOUSE NEAR CARDIFF.
}

(Plates v-vir.)

By R. E. M. WHEELER, D.Lit., F.S.A.

Modern students of Roman Britain have been taught to recognize the sharp line of cleavage, both social and regional, which intervened between the military and the civil zones of the province. Such recognition is essential both as a corrective to the indiscriminate marchings and counter-marchings of the earlier historians and as a safeguard against confusion in dealing with a comparatively restricted geographical area. The general validity of this distinction, however, is now so widely accepted that it is permissible to modify it in detail without risk of misunderstanding. It is evident, for example, that immediately behind the frontiers certain towns-notably Corbridgemust have contained a considerable military element; and, on the other hand, the forts themselves tended to become minor centres of civil life, generally of a poor and ill-developed order. Moreover, the banks or walls with which the larger and many of the smaller Romano-British towns were girdled during the occupation imply the existence, in esse or in posse, of some local organized force for their defence. It has been supposed that these walls are a late addition and were not in early times a normal feature of the Romano-British town plan. But it is certain that several of the Gallic cities were walled at a very early period, and in this country excavation has indicated that Colchester at least was almost certainly enclosed before the end of the first century. The walls of Aldborough were assigned provisionally by Haverfield to the second century. Roman Caerwent survived the construction of well-built bastions which were added to the town-wall, itself an addition to an independent earthen rampart; and we may suppose that this was of comparatively early date. ${ }^{1}$ Again, the Roman wall of London has been thought to contain work of two dates, and the bastions, at least some of which may safely be regarded as Roman, differ from both these works and seem to have been added after a considerable lapse of time. It is a reasonable postulate that the civitates of Britain, like those of $\mathrm{Gaul},{ }^{2}$ had their own local armed levies or train-bands for police-work and defence, and that there was an appreciable if unobtrusive military or semi-military element in the ordinary peaceful life of the province.

In these aspects, the Romano-British walled towns may be compared with the fortress-towns of the Middle Ages. It is, therefore,

\footnotetext{
1 There is indeed reason to regard this rampart as an original feature of the town.

${ }^{2}$ Coulanges, La Ganle romaine (1 891 ), p. 243.
} 
something of a paradox to find the neighbouring countryside teeming with un-walled, un-moated Romano-British residences, frequently many miles from the nearest refuge. It must often give cause for wonderment that, in the troubled years of the later third and fourth centuries, when the shores were infested with pirates and migratory hordes, and when the interior was ravaged from time to time by wandering gangs of brigands, the Roman country-house did not more often anticipate the domestic fortifications of the Middle Ages. The only surprise which such fortifications, when found, can occasion, therefore, derives from their rarity, and the banks and ditches

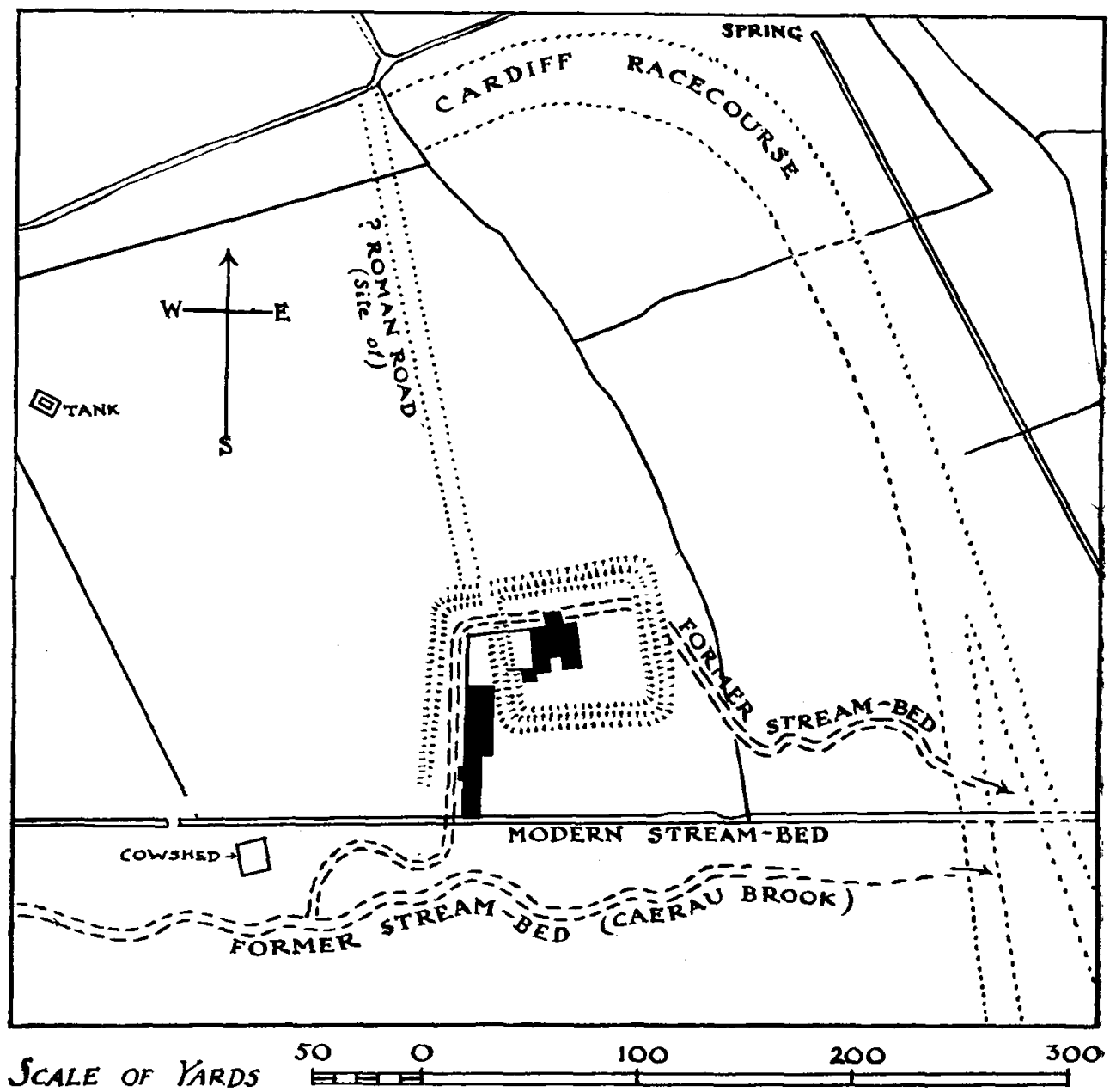

Fig. 3. SKETCh-PLAN OF THE SITE (height above o.d. between 30 and $40 \mathrm{ft}$.) (p.69).

Based on the Ordnance Survey Map (25 in. Glamorgan xlii, 13) by permission of the Controller of H.M. Stationery Office. 
which surround a Romano-British residence recently excavated in Glamorganshire may be said to add a new paragraph, but scarcely a new problem, to the history of Roman Britain.

The house in question lies two miles west of the Roman fort and mediaeval castle at Cardiff, and 500 yards from the west bank of the Ely at the point where that river, though still tidal, first becomes fordable. Some 600 yards to the north-west the present Cowbridge road closely represents the Roman way from Caerwent to Carmarthenshire, and it is claimed that the Roman road-metal has actually been seen alongside the present road near the Ely bridge. Some sort of track must have connected the Roman settlement with this road, but the faint indications marked on the ordnance map 'Roman road (site of)' and reproduced in fig. 3 failed to yield confirmatory evidence in a trial trench. ${ }^{1}$

The site of the Roman buildings is now encircled by the Cardiff racecourse, and its aspect has been drastically altered by drainage operations, which include the diversion of the Caerau brook into a straight channel immediately south of the Roman baths (see plan, fig. 3). The former course, or rather courses, of the stream can still be traced and are worthy of note in that they partially explain the lay-out of the buildings. The main stream followed a winding course about 70 feet south of the modern channel; but, a few yards above (west of) the site, it threw out a subsidiary streamlet which formed a loop towards the north. It was within the island formed by this loop and the main stream that the settler built his house. In order, however, to economize space and to drain the site, he straightened and deepened the stream-course to the west and north of the island, the two channels meeting in an oblique angle which determined the main lines both of the house-plan and of the later earthworks. The artificial stream-bed was cut to a depth of 5 feet, and the spoil-earth was thrown out in a low heap on both sides. Three trial-trenches through the ditch revealed a considerable depth of grey silt containing numerous branches and twigs of willow, fragments of brick and roof-tile, and a piece of Samian 27.

The choice of site is worthy of remark. Even under present conditions the ground is normally moist or even swampy, and was presumably more so in Roman times. The wooded slopes which rise towards the south offer dry ground within less than 300 yards of the brook. The reasons, therefore, for building on this little stream-girt island amongst the marshes are difficult to determine. The proximity of water not infrequently attracted rather than deterred the Roman builder, as in the case of the 'villa' on the banks of the Yeo at Great Wembersham in Somerset, or the recently

1 It is possible, however, that the surface has been
mostly destroyed by agricultural operations, and 
discovered fort near Capel Curig in North Wales, by the river Llugwy which must then, as now, have over-run it in winter flood. The presumption is that the motive both at Ely and in the Llugwy valley was the same, and that the Ely settler, sceptical of the penetration or endurance of the Roman peace in these outlands, preferred inaccessibility to comfort.

The banks and ditches which were ultimately added to the natural defences of the site attracted the attention of Mr. John Storrie, a local antiquary, in $\mathbf{1} 894$, and were then partially trenched by the Cardiff Naturalists' Society. ${ }^{1}$ These trenches were devastating, but at least revealed the presence of Roman foundations and even indicated the probability that the defensive earthworks were not an original feature. Traces of metal-working were found, but the plan or general character of the building was not ascertained. On behalf of the same Society the work was resumed in May and June, I922, by the National Museum of Wales, where most of the objects found in both excavations are preserved.

The excavated remains may be grouped broadly under three periods, although it is not implied that all the works included under each period are strictly contemporary.

Early Period. The earliest structures appear to have been the main or eastern block (Building I, on plan), and a secondary or western block (Building II) linked to the first by a rough boundary wall. The footings of these structures were everywhere laid in the virgin soil, and consisted of pitched slabs of the local lias, often arranged in herring-bone fashion. The walls themselves were wellbuilt, with rubble core and ashlar facing of lias. They were preserved to a maximum height of 3 feet, and up to that height contained no brick.

The main block, Building I, was of half-H shaped plan with the wings extending towards the south (fig. 4). The whole of the south front was faced by a single-storey verandah, carried on a wall of comparatively light construction. Where best preserved, on the eastern wing, this wall has a dressed foundation-course 2 feet wide, above which it is stepped back to a width of only $I$ foot 7 inches, thus contrasting markedly with the $2 \frac{\pi}{2}$-foot walls of the main structure. It was presumably not more than breast-high, and a small and fragmentary column-drum of Bathstone, Io inches in diameter, may be the solitary survivor of the dwarf colonnade with which, on analogy, it was probably surmounted. Between the wings was. an open entrance-court, paved with slabs and cobbles, and on both

\footnotetext{
1 Cardiff Nat. Soc. Trans. xxvi, pp. $125-8$ (fragmentary plan); Antiquary xxix, p. 234; xxx, p. 46, $208 ;$ Arch. Camb. 1894, p. $326 ; B . A . A$. 1, p. 326 ; Builder, lxvii, p. 244. The most complete summary (with sketch plan) was published
}

by Mr. John Ward, F.S.A., in the Cardiff Nat. Soc. Trans., L, pp. 24-44, but Mr. Ward was working from second-hand material, and his report, like the others, contains several errors. 
ROMAN BUILDINGS AND EARTHWORKS

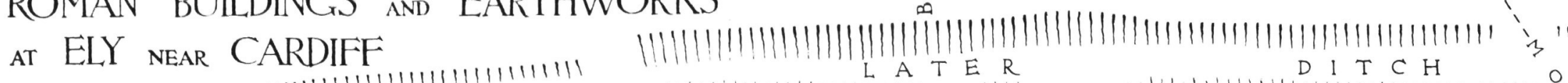

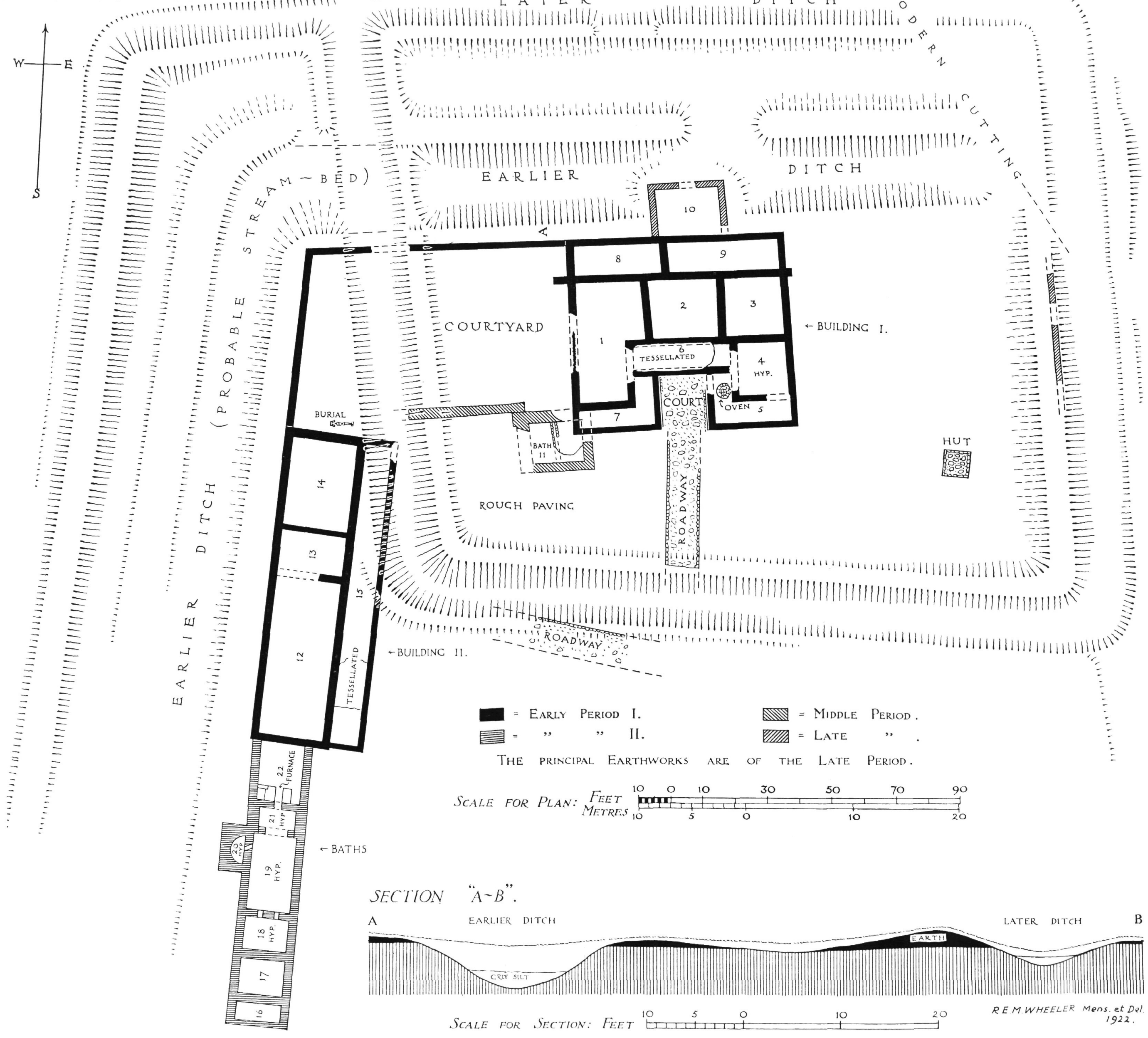

Fig. 4. ROMAN BUildings and Earthworks at ely, near CardifF. 


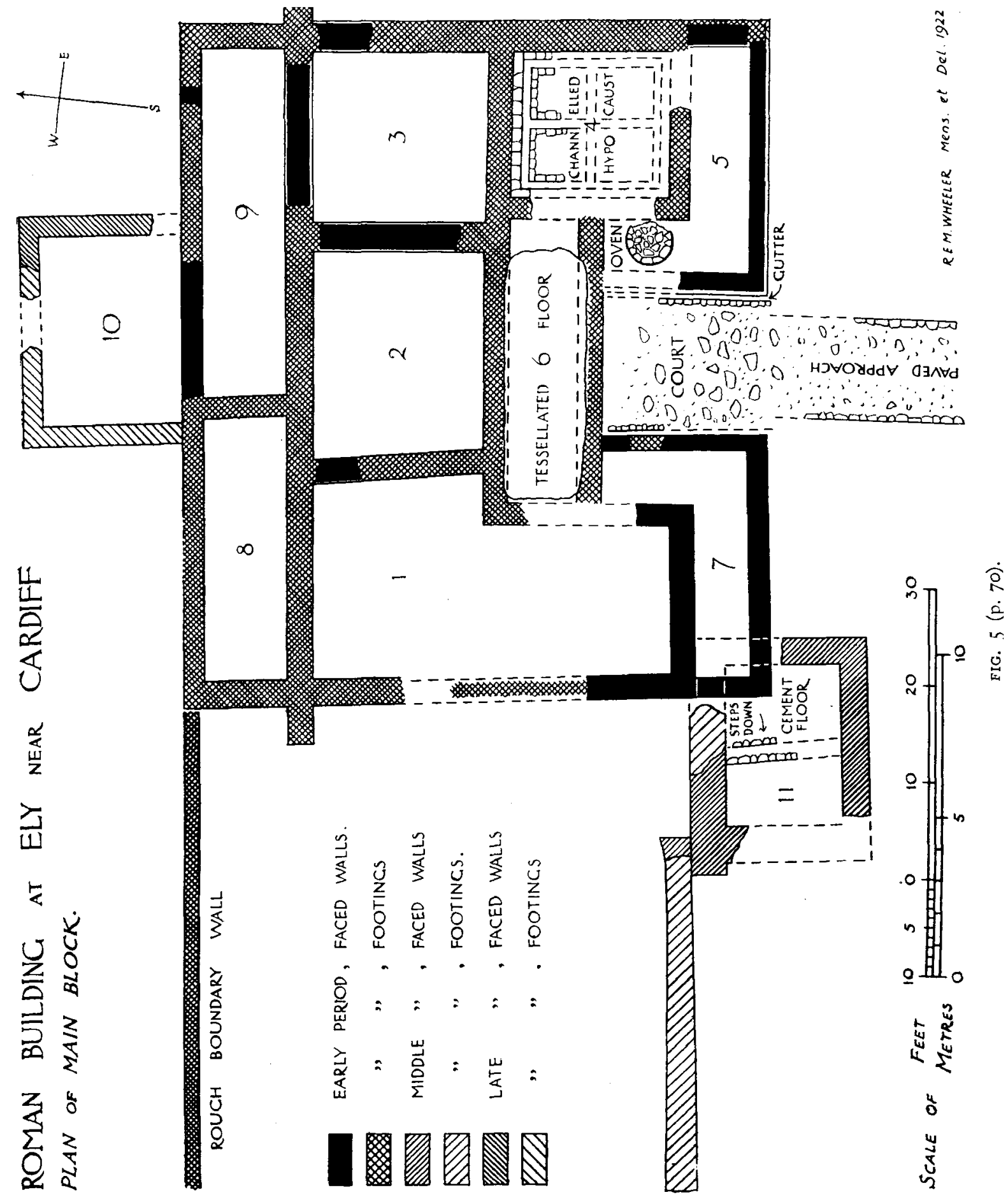


sides of this court were remains of stone gutters, 6 inches wide, which drained the rain-water from the pent-roofs of the verandah.

The original floors of the flanking verandahs had for the most part been destroyed, but that of the central strip, which fronted the main block and doubtless contained the principal entrance, showed two floor-levels. Both had been paved with tesserae, partly of brick and partly of pennant stone, but most of the tesserae of the lower floor had been re-used in that which was superimposed on it. It is noteworthy that the later floor, though conforming generally to the earlier plan, so far overlaps the adjacent footings as to suggest that the original stone walls had here been replaced at some period by timber walls built upon the old stone foundations.

At a comparatively late period a semi-circular oven had been inserted in the western verandah of the eastern wing. Only the floor of the oven remained, but it was clearly of the type which has been found on other Roman sites in Britain. ${ }^{1}$ Round it were large quantities of charcoal. It was associated with a very rough and fragmentary flooring of stone slabs and broken tile, which partly overlay an opus signinum floor that was itself a secondary flooring in this wing.

The main rooms of the house were four in number ( $1-4$ on plan). The westernmost (I) was L-shaped, and originally had a slab floor covered with a thin layer of yellow cement and carried on a bottoming of pitched stones heaped to a considerable depth in an effortprobably ineffectual ${ }^{2}$ - to ensure dryness. This early floor bore ample traces of fire; in places it was burnt red, and was strewn thickly with burnt wood, including remains of a $4 \times 1$ inch plank. Other rooms, especially 8 and 9, showed evidence of fire at this level, and it is probable that the original building was destroyed by a conflagration. In the present room a new floor of yellow cement on a rubble filling was subsequently built at a height of a foot above its predecessor. The filling contained a mortarium rim of comparatively late but undated type (fig. 5, no. Io).

The middle room (2) appears originally to have had a clay floor, but was afterwards re-paved soughly with stone slabs (including former building-stones) and broken roof-tiles. Many of these tiles had been distorted in the kiln, and must therefore have been made in the vicinity-doubtless from the clays which are still used for brick-making within a few hundred yards of the site. On this floor was found a 'third brass' of Constantine I, minted A.D. 320-4, the latest dateable object found during the excavations. The coin is in mint condition.

The adjoining room (3) was not cleared. The main room in the

1 As at Birrens, Great Chesters, Birdoswald, Housesteads, Haltwhistle Burn, Poltross Burn, Castleshaw and Gellygaer.
${ }^{2}$ After two months' continuous drought, water was found in this stone filling. 
south-east wing (4) had been badly damaged by the trial trench of I 894, but it had clearly been heated by a channelled hypocaust consisting of stone-lined channels 7 inches wide round the margins of the floor, with a similar dividing channel down the centre of the room. The plan of the channels, when complete, was probably cruciform, as at Wroxeter, 19I4 Report, pl. xii, I. It is noteworthy that the hypocaust had been disused and the channels largely blocked in Roman times, and that either before or (more probably) during this blocking a piece of window-glass and a potsherd of type probably not later than the end of the second century (fig. 7 , no. 9) were thrown into one of the channels. The original cement floor above the channels had been broken up, and had been replaced successively by two opus signinum floors. It will be seen that a similar fate befell the hypocausts of the baths, and indeed it must have been well-nigh impossible to maintain a hypocaust system on a site so liable to flood. The position of the furnace was not discovered.

On the northern side the house was backed for its whole length by a long verandah-like structure divided into two compartments. Here again, the outer (northern) wall, 2 feet in width, suggests a single storey, whereas the more solid main walls were clearly designed to carry two storeys.

It is not difficult to visualize the general appearance of the building in its original condition. The main entrance, flanked by the two wings, was approached from the south by a paved way, Io $\frac{1}{2}$ feet wide, consisting of slabs and broken stone between well-defined kerbs. The whole of the lower storey on this front was screened by the verandah, above which rose the bare walls of the upper storey pierced doubtless by the square windows depicted on Roman wallpaintings and mosaics, and crowned by a tiled roof, probably with flat-pitched gables over the wings. Buildings of this kind, generally on a more lavish scale, are not uncommon in Britain; Chedworth, Brading, Mansfield Woodhouse and Ickleton may be cited as prominent examples. These again vary in little more than size from Continental types, such as the 'villa' at Héronville in northern France or that called by Jacobi the ' Kaufhaus,' close to the Saalburg fort. ${ }^{1}$ The present building is distinguished amongst these by its unusual smallness and compactness, qualities which it shares with the small farms, of somewhat similar plan, which were characteristic of the Roman frontier territory east of the Rhine. ${ }^{2}$ These German examples, however, differed by the inclusion of a small internal courtyard, whereas the British types are shown by the occasional presence of mosaic floors to have been continuously roofed.

Both south-east and south-west of the house were found stretches

\footnotetext{
1 Other examples are collected by K. M. Swoboda, Römiscbe und romaniscbe Palaste, pp. $90 \mathrm{ff}$.

${ }^{2} \mathrm{G}$. Kropatscheck, 'Das römische Landhaus
}

in Deutschland,' in Kaiserlicbes Arch. Inst. VI Bericbt der römiscb-germaniscben Kommission, $1910-$ I I, p. 59; and Swoboda, as cited, pp. Ir I ff. 
of rough slab paving which had in some cases formed the floors of sheds. One of these floors, near the south-east corner of the later enclosure, was completely preserved, and is shown on the plan. Adjoining it on the south was a burnt area, about 20 feet in diameter, which yielded some of the earliest pottery found on the site (fig. 7 , nos. 27-3I).

Building II seems to have been approximately contemporary with Building I. Its footings were everywhere built on the clean natural surface; and close to them, on the same level, were found a piece of roughcast slip-ware, a grey sherd with the wavy combed pattern which seems to have died out before the Antonine period, and a few other fragments to which a similar date can be assigned. The building was of simple oblong plan, and consisted of three

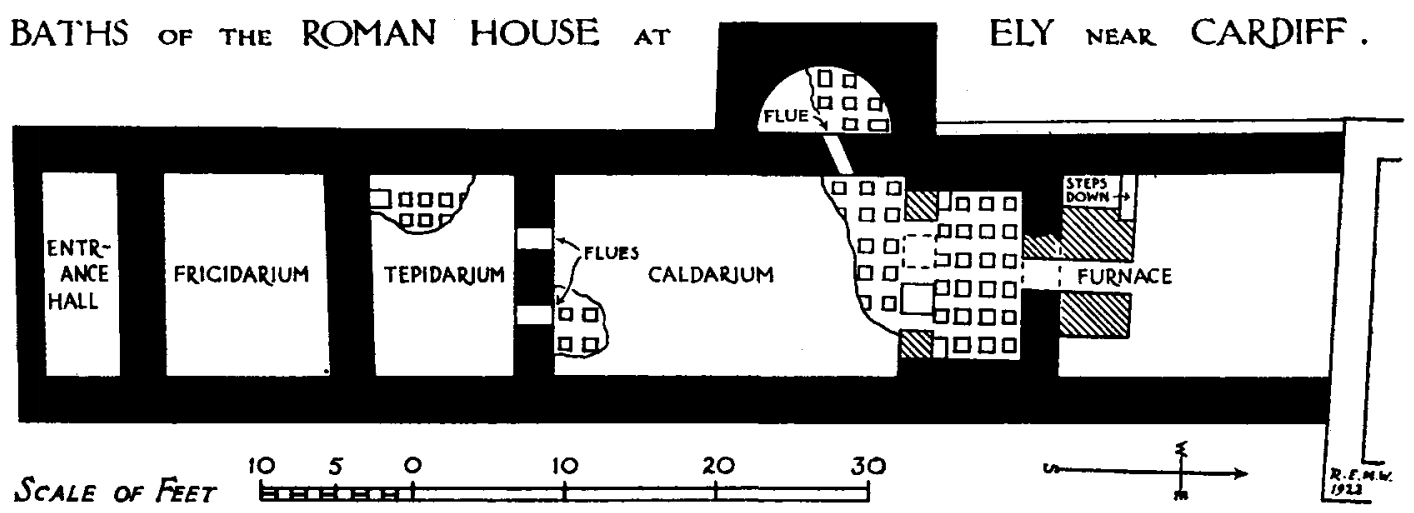

FIG. 6 (p. 75).

slab-paved rooms, possibly workrooms, although on the east they opened on to a corridor which retains part of its pavement of red and grey tesserae (brick and pennant) laid in 7 inch longitudinal stripes. On the floor of the main southern room (12) a small hearth for smelting iron is said to have been discovered in 1894 . The block, unlike Building I, was roofed with hexagonal slabs of pennant stone.

This building was approached from the east-south-east by a pathway similar to but less well preserved than that already described. A considerable length of kerbing remained on the northern side of this approach, and against it, in a well-defined layer, were found two fragments of early Samian (form I8/3I) and a fragment of a ringnecked jug of a type which can scarcely be later than A.D. I 30-I 40 (fig. 7, nos. 6-7).

The chronological evidence of the early second century pottery found here and elsewhere on the site (see below, p. 83) is supplemented 
by that of the coins found in I894. They were lost shortly afterwards, but are vaguely recorded to have been bronzes of 'Augustus' and 'Nerva' and a denarius of 'Antoninus Pius.' The first and last perhaps require further identification, but the margin of error in the case of the second is small, and this coin may be used as auxiliary evidence. It is clear that the site was first occupied within the first thirty or forty years of the second century, and we may reasonably associate with this occupation Building II (without the baths) and the first plan of Building I.

Adjoining the south end of the western block is a small but complete set of baths (fig. 6). These are certainly an addition to the block against which they abut, and the north-west angle of the apsidal chamber was built across a small rubbish pit, which yielded a few pieces of pottery of the first half of the second century (fig. 7 , nos. I-4). No other evidence of a previous occupation layer was observed, however, in this area, and it seems not improbable that the baths were added at no great interval of time after the building of the adjacent blocks.

The baths were entered through a small verandah at the south end, and consisted successively of a cold-room, a warm-room heated through two corbel-arched flues (plate v, no. I) from a larger hot-room, which was also connected on the west by a diagonal flue with a small chamber externally rectangular and internally apsidal (plate vr). The apsidal chamber may have contained a water-bath, all traces of which had been removed in Roman times. Between the hot-room and the furnace was a small room, the thickened walls of which probably carried a second bath, heated directly by the adjacent furnace. The northern wall of the room was carried across the furnace by an arch of which a springer remained on the east side. The furnace was approached from the west down two stone steps. All the heated rooms showed remains of brick pilae.

Baths of this simple type are a well-known feature of the conventional Romano-British residence, and the penetration of 'Romanization' finds no more striking proof than in the crude hypocausts with which even the rough native farmers of the Hampshire downs occasionally sought to modify the discomforts of their primitive kraals. But whether the occupants of the Ely residence wearied of their adopted luxury or whether, as is perhaps more probable, the continual flooding of the hypocausts rendered the system unworkable on this low-lying site, the heating system was disused during the Roman period, the flues were blocked with brick and masonry, the floors were broken up and thrown amongst the pilae together with old building stones, painted wall-plaster and other débris, and over this rough filling was poured a thick layer of pink cement. Subsequently this cement floor was wholly or in part renewed by a second thick layer of similar material (plate vir, no. I). 
Here again, the absence of dateable objects in the comparatively small area cleared leaves the absolute chronology indeterminate. It is a possible inference that the complete gutting which the building evidently underwent when the floors and walls were stripped and the hypocausts filled up, indicates the rehabilitation of a decayed or damaged building and should be brought into relation with the disaster which, as recorded above, appears to have overtaken Building I during the earlier part of its history.

Middle Period. It was perhaps in connexion with the partial reconstruction of the main block and the filling up of the hypocausts in the bath-block that a new and substantial structure was added to the south-western corner of the former. This new structure consisted of a rectangular chamber with walls varying from 3 to 5 feet in thickness. Time and the trench of 1894 have destroyed much evidence here, but it is certain that these walls overlay the original verandah and perhaps even the corner of the wing itself; part of the yellow cement flooring still remained in situ at a height of 15 inches above the foundations of the western verandah-wall. It is clear, therefore, that in re-building or restoring his residence, the occupant of this period abandoned some of the features of the original plan.

A foot or more of 'occupation soil' containing much burnt wood had accumulated before this new room was added. Into it had been thrown as ballast a number of disused building stones, and on this basis the new walls and floor had been built. The floor, as preserved, consisted of rough stone slabs, which had apparently been covered by a layer of hard yellow cement. The eastern half of the floor was raised by the height of two stone-faced steps of cement, and the whole arrangement suggested a former plunge-bath with the steps (or a seat and a step) on its eastern side. It would be logical to regard this bath as a simple substitute for the more elaborate system which it had been found desirable or necessary to discard. Much wall-plaster, painted in stripes of red, brown, yellow and blue, was found in and about this building, and the earlier excavators seem to have found a piece of quarter-round plaster moulding in situ against the northern wall.

Bonded into the north wall of this room was the foundation of a wide but roughly-built wall which proceeded westwards until cut by the later ditch. It probably served as a southern boundary to the north-west courtyard, although the earlier excavators speak of some sort of a decayed floor to the south of it.

Late Period. In the third or late period, the site underwent drastic changes. The earlier ditch on the north of Building I was largely filled up and at one point on the northern side of this building a projecting room (10) was built across the filling. The area containing Building I was now surrounded by a bank and a ditch 

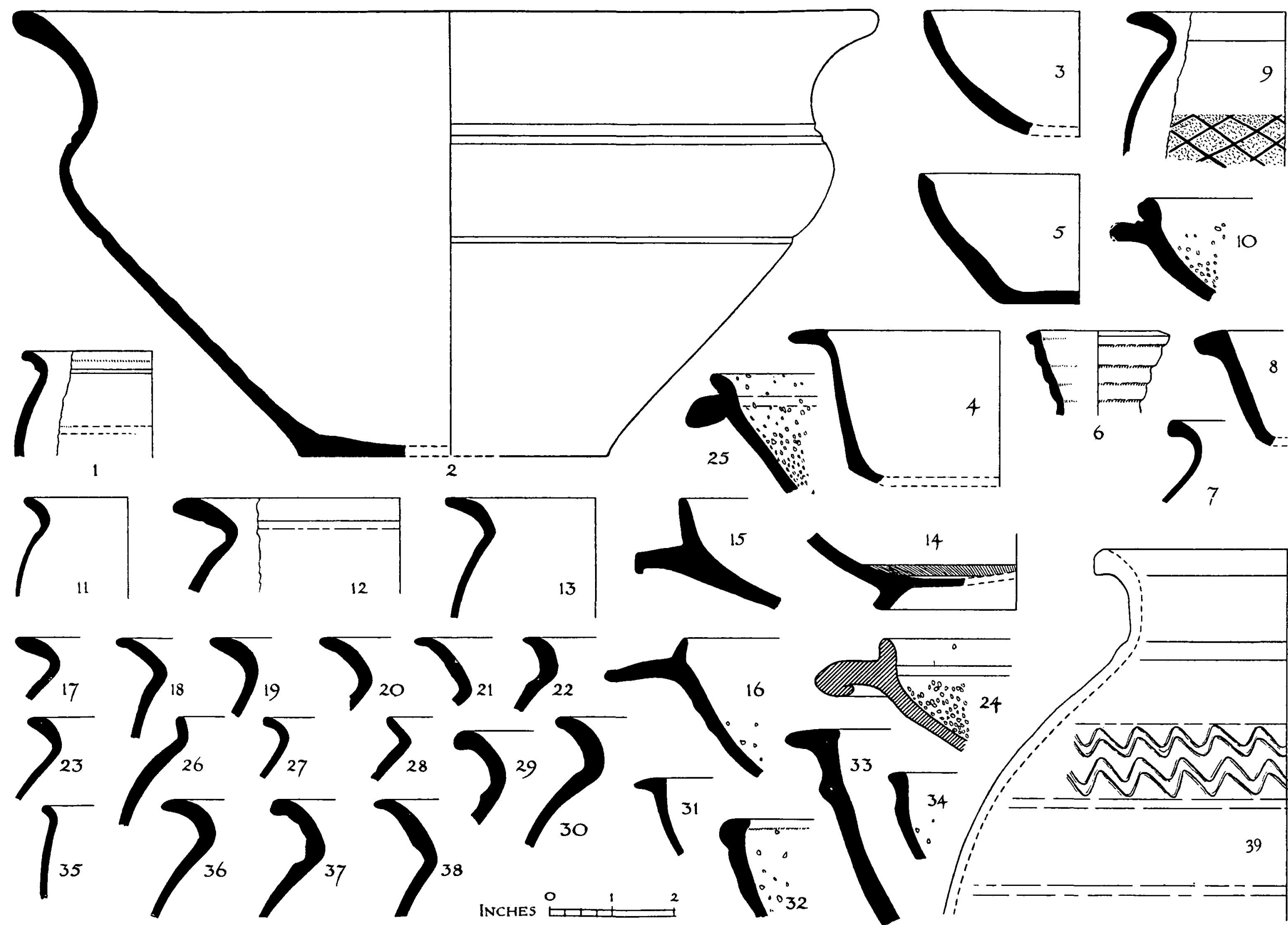

)

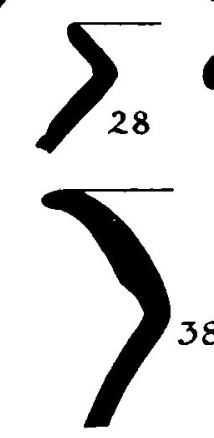

INCHES
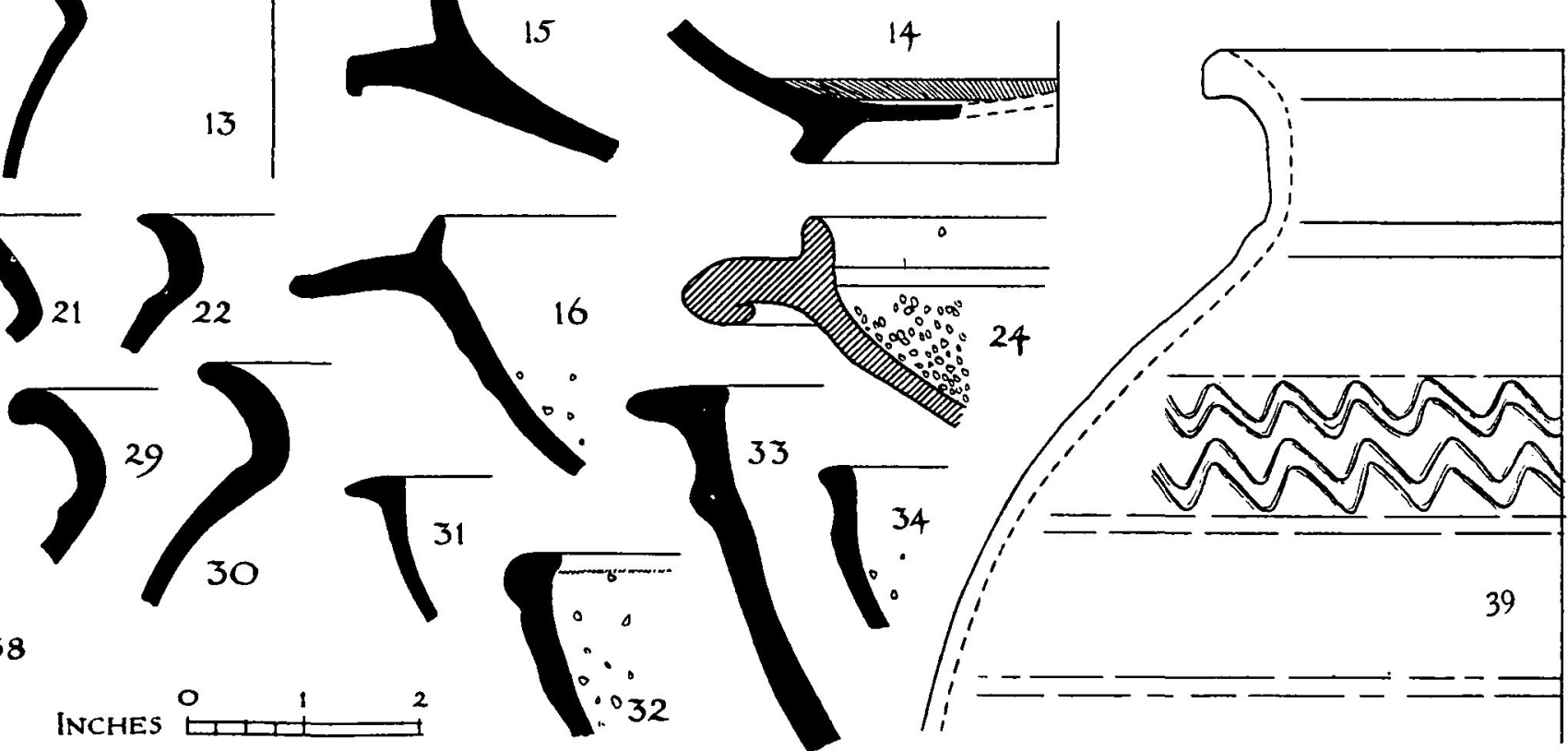

FiG. 7. POTTERY FROM THE SITE. 
forming an enclosure of rhomboidal plan, measuring approximately Igo feet from the east to west, and I70 feet from north to south. The stream was apparently diverted along the new northern ditch, but the gradients seem to have been so arranged as to keep most of the ditches on the west, south and east sides dry under favourable conditions. In addition to the main enclosure, the area occupied by Building II and the baths was included within an outwork of L-shaped plan, the shorter arm of which approached but did not join the north-west corner of the main work, whilst the longer arm extended southwards towards the natural winding course of the stream. A considerable stretch of the stream bed was thus included within the new defences and the absence of any definite indication of a corresponding outer defence on the eastern side $^{1}$ is readily explained by the extremely marshy character of the ground at this point, which is somewhat lower than the remainder of the site. Indeed, although the ground has been disturbed here in modern times, there are still remains of a secondary bank built along the outer side of the main east ditch to dam back the adjacent swamp.

The relative date of these earthwork defences is readily apparent. The trench of 1894 had indicated that the western ditch of the main enclosure partially encroached upon a pre-existing floor or pavement on its eastern side, and the inference drawn from this has now been confirmed and amplified beyond question. The western ditch was cut through the north-eastern corner of Building II, and the counterscarp was built over the foundations of this building to a height of 2 feet above the footings. The long wall extending westwards from the bathroom (II) which was itself an addition to Building I, was similarly cut at its western end, and the main bank was apparently built over it - the only doubt on the latter point arising from the disturbance of the ground here in 1894 . Further north, the cutting of the same ditch demolished part of the boundary wall which linked Buildings I and II on this side; whilst at the south end the main rampart was built partly over the rough slab paving of a previous period. Moreover, everywhere on this side an earlier 'occupation layer' containing much burnt matter underlay the bank. On the south side the rampart was carried across the broken end of the paved approach to Building I and the ditch had been cut through the roadway which had formerly approached Building II. The kerbstones of the latter roadway were found passing diagonally through the counterscarp of the ditch.

It is thus beyond doubt that these earthworks not only superseded parts of the Early Period buildings but were also later than the Middle Period additions. It is further possible with some prob-

1 There are what seem to be slight traces of a
former ditch extending southwards from the south-
east angle of the enclosure, as indicated on the plan.
It was not possible to excavate this, and the superficial indications are here obscured by modern alterations of the ground. 
ability to reduce this evidence to terms of absolute chronology. In the occupation layer which lay beneath the south-western corner of the enclosure rampart was found a 'third brass' of Claudius Gothicus (A.D. 268-270). ${ }^{1}$ It will be remembered also that a "third brass' of Constantine I, minted A.D. 320-4, had been dropped whilst in mint condition on the surface of the latest floor of Room 2. The evidence of two coins must not, of course, be pushed too far, but, reinforced by the pottery found under the west bank (fig. 7 , nos. I7-24, second to third centuries), they suggest that the earthworks may have been built between A.D. 270 and 325. That the coin of Constantine represents approximately the latest period of occupation is suggested also by the pottery, which includes no specimens distinctively of late fourth century date, ${ }^{2}$ and the position in which the coin was found also suggests that it cannot have been dropped long before the end. On general grounds-the depth of the occupation layer over which even the Middle Period building had been constructed and the definite priority of this construction to the earthwork-it is permissible to infer that the defences are of comparatively late date, and the coin of Claudius Gothicus as a terminus post quem is quite in accordance with probability. The later limit is less securely established, but we may reasonably suppose that the earthworks were added within a quarter-century of A.D. 300.

There is evidence of little building activity in the last phase of occupation, but to the Late Period may be assigned the room (I0) on the north of Building $\mathrm{I}$, and the boundary wall of which a fragment remains on the summit of the eastern bank. 'The room, as mentioned above, was built across the earlier northern ditch which had been filled up with disused building material to carry it. The eastern boundary wall lay so near the present surface of the ground that it had been almost entirely removed and its former extent is uncertain. Building II had evidently been reduced largely or wholly to its foundations, which had been covered with earth to form a level platform within the annexe; but it is possible that the former bathbuilding, now converted to other uses, was still retained. It is not improbable, however, that the main purpose of the annexe, apart from enclosing a useful stretch of stream, was to form an enclosure for cattle in case of need. Indeed, the deliberate covering of the earlier building suggests that such was the case. Incidentally, however, this area was used on at least one occasion as a cemetery. Immediately north of Building II was found a human skeleton buried east and west ( 96 degrees magnetic) with the head at the west end (plate v, no. 2). The skeleton had been interred on a level with

\footnotetext{
${ }^{1}$ A coin of Carausius was found in the filling over the W. wall of Building II, but was less clearly stratified.
}

${ }^{2}$ This statement is based primarily upon a comparison of the Ely pottery with that from the latest occupation of Segontium c. A.D. 350-330. 
the footing at a depth of 2 feet 8 inches beneath the present (and approximately Roman) level, and lay between a headstone and a footstone with a supplementary stone on each side of the head. The pelvis rested upon one of the hexagonal slabs of pennant with which Building II had been roofed. The careful orientation of the body and the absence of grave furniture suggest, but do not prove, that the burial was that of a Christian. Sir Arthur Keith, F.R.S., who has kindly examined the skeleton, writes:-

' It is that of a man, about 5 feet 5 inches in height, with bones of slender development-clearly not one who did manual labour. From the teeth, all of which are worn on the chewing surfaces but free from disease, and the state of the sutures of the skull, I infer he was over forty years of age and under sixty. The measurements of the skull (length $190 \mathrm{~mm}$., width $146 \mathrm{~mm}$., height I $20 \mathrm{~mm}$.) are those generally obtained from burials of the Roman period in England. It falls into the mesocephalic group with a cephalic index of 77. The shape of the head, the steep but not high forehead, the relative lowness of the cranial roof, and its width and length, are all characters of the people found in stone graves of the Roman period. The lower jaw is square and the chin strong and prominent. The skull is remarkably thin; its thickest parts along the roof do not exceed $5 \mathrm{~mm}$., while at the sides the thickness is only 2 or $3 \mathrm{~mm}$. The cranial capacity is calculated to have been $\mathrm{I}, 525 \mathrm{cc}$.-well above the modern mean for Englishmen.'

Throughout the recent excavations abundant traces of ironworking were observed, and the earlier excavators claimed to have found two of the actual hearths on which the ores were smelted. ${ }^{1}$ Partially fused slag was actually used as a paving for the open space immediately east of Building II, and it may be noted that a similar paving was used for the main streets of the Roman fort at Cardiff. It is of interest to find on analysis that some of the ores used are associated with manganese, whether by accident or design it is difficult to say. Mr. R. W. Atkinson, B.Sc., who has an intimate knowledge of the ores of Glamorganshire and the neighbouring counties, states that the specimens submitted to him ' resemble a manganiferous iron such as we get at present from the south of Spain. I am not acquainted with any such ore from the near neighbourhood of Cardiff. A manganese ore does occur in small quantities in Glamorgan, near Pyle (25 miles from the Ely site), but it does not resemble this material.' It is indeed recorded that a small amount of manganese occurred in the old Trecastell mine near Llantrisant, about 8 miles north-west of Ely, but it seems at least possible that the manganese at Ely was brought from further afield. The effect of the manganese

${ }^{1}$ Cardiff Naturalists' Society's Trans. xxvi (18934), p. I29. Full analyses, kindly prepared by Mr.
R. W. Atkinson, B.Sc., will be published shortly in the Transactions of that Society. 
would, of course, be to produce a steely iron of greater hardness than that produced from ores not containing manganese.

Summary:-The evidence thus indicates that in the first half of the second century a moderately prosperous Romano-British establishment was built in the well watered and thickly wooded Ely valley within easy reach of a main road and a tidal river. Good building-stone and clay lay to hand, but some freestone was brought over from Somersetshire, possibly as ballast. The main industry was apparently iron-working, for which ores were available within two miles of the site, although manganese or a manganiferous ore was possibly imported from some more remote locality. Whatever the social status of the householder, he was thoroughly ' Romanized,' and his house and the baths which he added, if on a small scale, conformed to normal provincial Roman types.

The subsequent history of the site was probably one of devolution. The bath-wing was converted to other purposes, and though for a time a simpler bath-block, solidly built and characteristically decorated with crudely painted plaster, seems to have carried on this essential feature of a well-regulated Roman ménage, the buildings generally appear to have fallen upon evil days and were perhaps partly rebuilt in timber. Finally, the secondary block (Building II), which, as the abundance of fallen building material on the site suggests, may already have fallen into ruins, was levelled and superseded by a system of banks and ditches designed to enclose the main residence and a small annexe. Reason has been shown for assigning this final remodelling of the site to the third or early fourth century A.D.

It is possible to trace in the story of this small settlement some reflection of the larger historical issues of the time. Excavations during the last twelve years have confirmed and partially filled in Professor Haverfield's preliminary outline of the Roman occupation of Wales, and have shown that the garrisons which were poured into the peninsula during the latter part of the first century were largely withdrawn or reduced before the Antonine period. There were local recrudescences of military activity during the third and fourth centuries, but for the most part the natives of central and northern Wales were left to their own devices and continued to build their rough round huts and fortified hill-towns. Neither the few Roman outposts which were probably retained at certain strategic points, nor the scattered mining centres of Flintshire, Anglesey, Carmarthenshire and elsewhere were likely to become effective centres for the diffusion of Roman civilization amongst scattered hill-tribes who had scarcely yet come into touch with the later Iron Age movements beyond the Marches.

From this dual system-the few Roman garrisons with their camp-followers in the valleys and the native herdsmen and cultivators amongst the uplands-only in one region was there any 
marked departure. ${ }^{1}$ The fertile, low-lying lands which look southwards to the Bristol Channel attracted a few settlers of more sophisticated type, and along these coastlands and the adjacent rivervalleys something approaching a regular Romanized civil life gradually came into being. In Gower, and as far west as Abercyfar, near Carmarthen, tessellated or mosaic pavements have been found, and the pleasant valley of the Usk at Llanfrynach below Brecon was chosen apparently for the site of an extensive country residence. Nearer Cardiff are two sites which, in the present state of knowledge, seem to be the most important of the series. One of these is that now under consideration; the other is a large dwelling-house which was discovered and partially excavated in 1888 at Llantwit Major, some I4 miles further west. The complete plan was not ascertained, but the surface indications seem to indicate an extensive building of courtyard type. The walls are apparently standing to a considerable height immediately beneath the turf and the whole site would amply repay thorough excavation. The trenches of 1888 are said to have revealed parts of fifteen rooms, in some cases with walls still standing 9 feet high, and retaining remains of painted wall plaster. The especial interest of the site, however, was a large double room measuring 39 feet by 27 feet, and paved with elaborate geometric mosaic of which a coloured engraving is preserved. 'In laying bare the pavement of this hall, no fewer than 4I human skeletons of both sexes.and all ages have been met with, and among them the bones of three horses. In one instance the human skeleton lay beneath that of a horse in such a position as to indicate that the horse had crushed and killed the man by falling upon him. It is evident that this hall had been the scene of a massacre, for in nearly every instance the skull or facial bones had been fractured, and the bodies lie over one another in confused heaps. In four instances there had been an attempt at burial. For this purpose the pavement was torn up and the body laid in an opening not more than six inches deep, its feet towards the east and then surrounded with stones in the form of a coffin and covered with a few inches of earth. The unburied bodies belong to a small race with brachycephalic skulls; but those that are buried were clearly men of a larger size and had skulls of the dolichocephalic type. It is reasonable to suppose that the former represent the natives of the district and the latter the attacking party.' ${ }^{2}$

With all due allowance for the ready imagination of the excavators, it is clear that they had stumbled upon a vivid chapter in early Welsh history. It becomes a matter of considerable importance to ascertain with certainty the approximate date of the disaster

\footnotetext{
${ }^{1}$ For references, see Cymmrod. Soc. Trans. 1920-1, pr. $81 \mathrm{ff}$.
}

2Arch. Camb. 1888, p. 4r4. See also Cardiff Naturalists' Soc. Trans. xx (1888), pp. $50 \mathrm{ff}$. 
which seems to have been revealed. Most of the objects found during the excavation are now in the National Museum of Wales, where I have examined them. The pottery seems to be for the most part of Middle rather than Early Empire date, but here, as at Ely, distinctively late types are apparently absent. Six or seven coins appear to have been found. Of these one, now lost, is said to have been Greek ' but nothing more can be said of it, as only two letters of the legend are legible.' It was presumably a Greek (or Eastern) Imperial coin, such as that of Gaia Cornelia (A.D. 253) which has been found in the Roman fort at Cardiff. ${ }^{1}$ Five coins from the Llantwit site are still preserved and are of Gallienus, Victorinus, Quintillus, Tetricus Senior and Maximianus I, i.e. they were all minted between A.D. 254 and 305. These coins are all in good condition and that of Maximianus is in mint condition. A provisional deduction from the evidence available therefore will place the principal period of occupation in the latter part of the third century, and it is tempting to suggest that the destruction took place then or shortly afterwards. If this provisional deduction be confirmed by future excavation, the evidence of the Llantwit Major building will conform with other evidence from the south Wales coast. Three milestones (two of Diocletian and one of Maximinus) indicate that the Roman main road through Glamorganshire was extensively repaired at this time, and to the same period may reasonably be assigned the rebuilding of the fortress at Cardiff on a large scale with projecting polygonal bastions. ${ }^{2}$ It is natural to bring into connexion with this the Irish troubles of the period and the recorded migration of at least one Irish tribe into western Wales. Whether the long-headed victors of Llantwit Major hailed from Meath must remain conjectural, but it was doubtless the risk of molestation from the direction of Ireland that impelled the extension of the Saxon shore system as far west as Cardiff.

From these facts and inferences, it is no great step to bring the fortification of the Ely building, about A.D. 300, into line with the general defensive and offensive activities of the period. Fancy, might suggest that it was the fate of the Llantwit Major 'villa' that persuaded the prudent owner of Ely to take timely precautions, and indeed his building, within easy reach of a navigable river, must have stood in a position of considerable peril from the sea-borne raider. At a time when Romano-British towns seem to have built or strengthened their walls and when, as excavation has shown, the native Welsh tribesmen overlooking the coasts of North Wales at Dinorben rebuilt the massive ramparts of their hill-town, it is not unnatural to find a private householder following the same example 
on a small scale. It is indeed rather matter for remark that other examples of domestic fortification in the late Roman period have been so rarely observed or recorded. The closest analogy is perhaps the partially excavated house and baths within the Castle Dykes near Ripon. ${ }^{1}$ A small building excavated at Cwmbrwyn in Carmarthenshire was surrounded by a bank and was apparently occupied at the end of the third century A.D., ${ }^{2}$ and at Bartlow in Cambridgeshire earthworks are more or less vaguely associated with a Roman 'villa.' 3 But these are exceptions. On the Continent an attempt has been made with doubtful success to trace the evolution of the mediaeval fortified mansion from the enclosed Roman 'villa' through the intermediary Carolingian farmstead. ${ }^{4}$ In Britain no such continuity can be expected, but the Ely villa is an interesting anticipation of the domestic fortification of a later age.

1 Arcb. Fournal xxxii (1875), p. 135 .

2 Arch. Camb. I907, p. I75. Cymmrod. Soc. Trans. I908-9, p. I62.

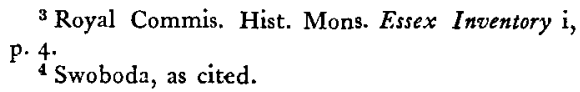

NOTE :-Full publication of the 'finds' is reserved for the report which will be published in the Cardiff Naturalists' Society's Transactions, but the pottery, as of some historical value, is briefly noted here.

Little information regarding the chronology of the pottery was forthcoming, partly owing to the proximity of the remains to the surface, but largely by reason of the scarcity of coins and Samian. The scarcity of Samian is curious, since the neighbouring main road led to the gates of Caerwent, some 25 miles to the east, while the well-populated lands of Somerset and Gloucestershire lay within easy reach. One of the fragments had been rivetted, and, more significant, pieces of the commonest grey ware, pierced for rivets, seem to indicate a need or desire for economy. There was perhaps little traffic along the south Wales coast, and even thoroughly Romanized establishments such as those of Ely and Llantwit Major may have been out of touch with the main currents of RomanoBritish life.

Thirty fragments of Samian have been found on the site, but they include no potter's marks. Amongst the earliest are two pieces of $18 / 31$, found respectively against the kerbstones of the approach to Building II and in the burnt heap near the hut in the SE. area. In the same heap were fragments of a shape 33, of fine fabric and good glaze, and the base probably of a 27. Another piece of 27 was found in the earlier northern ditch. The decorated Samian is limited to three fragments of 37 , which show only egg-and-tossel or straight-wreath patterns; the base of another bowl of coarse and late appearance was also found. The remaining fragments are all of shape $3 \mathbf{I}$, and vary considerably in quality of fabric and glaze.

The coarse ware (fig. 7) was for the most part very fragmentary, but generally confirms the chronology suggested above.

I-4 were found together in a small rubbish-pit which partially underlay the northwest corner of the apse of the bath-building.

I. Light grey ware, of well-levigated clay. Typologically it lies between the Segontium type (Arcb. Camb. I921, p. 201, Nos. I and 5), dated I10-125, and the Balmuildy type (S. N. Miller, Roman Fort at Balmuildy, pl. xlvi, No. 9), dated 140-180. It is nearer the latter, and is slightly heavier than the Gellygaer examples, which are probably Trajan-Hadrian. The present example may be provisionally dated $c$. 120-I50. 
2. A wide-mouthed bowl, light grey. Similar to but slightly bolder in outline than $W$ roxeter, I9I 4 , No. 78 , which is not precisely dated, but ' a few have been found in not very well-defined second-century deposits, the majority having been met with in association with later wares.' The general appearance of the present example is early, and it was definitely associated with No. I.

3. A small grey bowl without special characteristics; associated with No. I.

4. Well-made grey bowl with flange and bevelled base. Analogies with Gellygaer examples (Trajan-Hadrian). The Balmuildy and other Antonine examples of this type are less sharply defined, and the bevel in particular tends to become rounded after the first quarter of the second century.

5. Similar to No. 3 but rather coarser; was found in the soot of the basement floor of the hypocaust of Room 4. It had evidently been thrown in through the furnace when the hypocaust was still in use.

6-7 were found with three early-looking fragments of Samian 18/3I, and a piece of roughcast ware in a well-defined layer low down against the kerbstones of the approach to Building II, under the counterscarp of the later ditch. The group can scarcely be later than the first quarter of the second century.

6. Ring-necked jug of buff ware. Analogies from the early period of Newstead (not later than Trajan), and Wroxeter, I9I2, Nos. I and 3 (A.D. 80-I30), and many other sites. The most complete series of dated ring-necked jugs - that in the Trier Museumhas not been adequately published.

7. Grey ware. Compare Segontium, I921, No. 7 (c. A.D. I10-125). Analogous types survived into the Antonine Period, as at Balmuildy (Miller, op. cit. Fl. xlv, nos. 2 and 3).

8. Grey ware. The type was in use during a long period and cannot be satisfactorily dated, although the bevelled base in the present example is probably an indication of fairly early date.

9. Found in one of the blocked channels of the hypocaust in Room 4 of Building I. It is thus prior to the renovation of this room, when the hypocaust was disused and filled with cement. With the potsherd was found a slab of window glass, and it is possible that these objects were thrown during the rebuilding of the house which has been postulated above. The rim, black ware, is analogous with Antonine types at Balmuildy (cp. cit. Fl. xlv, 7-8), and lasted with little variation until the fourth century (May, $T$ be Pottery found at Silcbester, pp. 159-160). The rim alone is insufficient for more precise dating, and even under favourable conditions ollae of this kind are still of uncertain value for purposes of chronology. It can, however, be said with some confidence that the present example is not earlier than the Antonine period, and may be as late as the following century.

10. Was found in the filling between the earlier and the later floors of room 1 of Building I. It is a buff mortarium rim with white and brown spar. No similar examples are recorded from the Antonine wall, and though this small and rather malformed type is commonly regarded as late, precise evidence seems to be lacking.

II-I 2. Black rims deep down on the surface of the natural soil by the footings of Building II. These types lie midway between the earlier and the later Newstead series, but find analogies of the Antonine period at Balmuildy (op. cit. pl. xlv). A rim almost identical with II was found in a second century (probably Antonine) deposit at Corbridge (I9I I, pl. xi, 53).

13. Dark grey ware; was found under a slab of the flooring of Building II. This floor is apparently not original; the room seems to have been paved at first with a hard deposit of iron slag. The pronounced overhang of this rim suggests a post-Antonine date.

14-16. Were found in the south rampart. I4 is imitation Samian, of fairly fine fabric. $I 5$ is an orange-buff flanged bowl; 16 is of similar ware with a very few fragments of spar embedded towards the bottom of the fragment. Both these are well-made and of early appearance, but no dated analogy appears to be available. 
17-24. Of grey or black ware; were all found in the occupation layer which underlay the western rampart, and therefore ante-date it. They seem to represent a considerable period, extending from the first half of the second century $(17,23,24)$ to perhaps the end of the third century (18). 24, a light buff mortarium with large grains of white and brown spar, is an early type which just survived into the Antonine period (approximate examples at Balmuildy); whilst 18 approaches the types which have been found in association with Constantin an coins (May, Silchester, p. I60). The development of ollae such as 18 , however, was slow and doubtless unequal.

Two other mortaria of early type similar to 24 have been found on the site. A few later types, unstratified, also occurred, such as 25 (light buff ware, coarse brown spar) which may be described as a decadent descendant of 24 ; it is apparently without analogies earlier than the third century, but definite information is lacking.

26-31 are representatives of a large number of sherds found in a burnt heap SE. of the 'hut' shown on the plan. The heap contained early Samian ( 18 or $18 / 31$ ), and rims similar to 27 and 28 occurred in the early ditch at Newstead. The whole group is probably not later than $c$. A.D. 130 .

32-39 are unstratified but are illustrated as representative of the site. 34 resembles Balmuildy, pl. xlv:i; $3 \mathbf{I} ; 38$ is a late type (see above, No. I 8 ); 36 has Antonine analogies (Balmuildy, pl. xlv); and 39 is almost identical with an example found at Gellygaer (Trajan-Hadrian). The type had a long life, but the wavy combed pattern seems to be pre-Antonine. Three fragments bearing this pattern were found on the site, in one case with a piece of roughcast slip-ware beside the footing of Building II. 


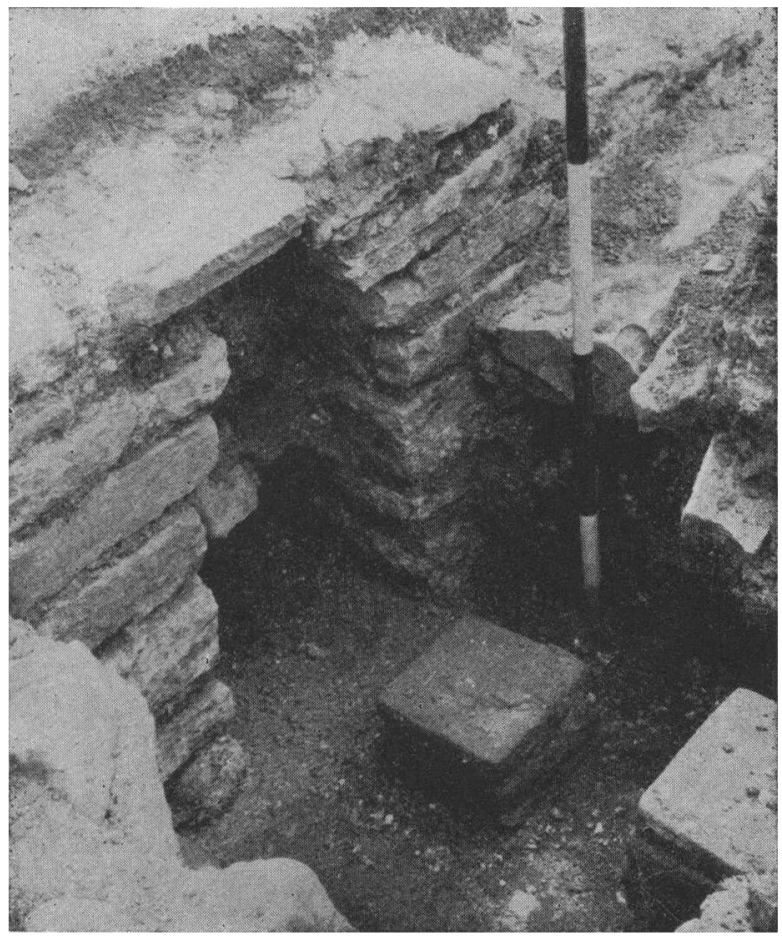

NO. I. ROMAN BUILDINGS NEAR CARDIFF: BLOCKED FLUE BETWEEN ROOMS 18 AND I9, AND ROMAN FILLING CUT BACK To show original pilae (p. 75).

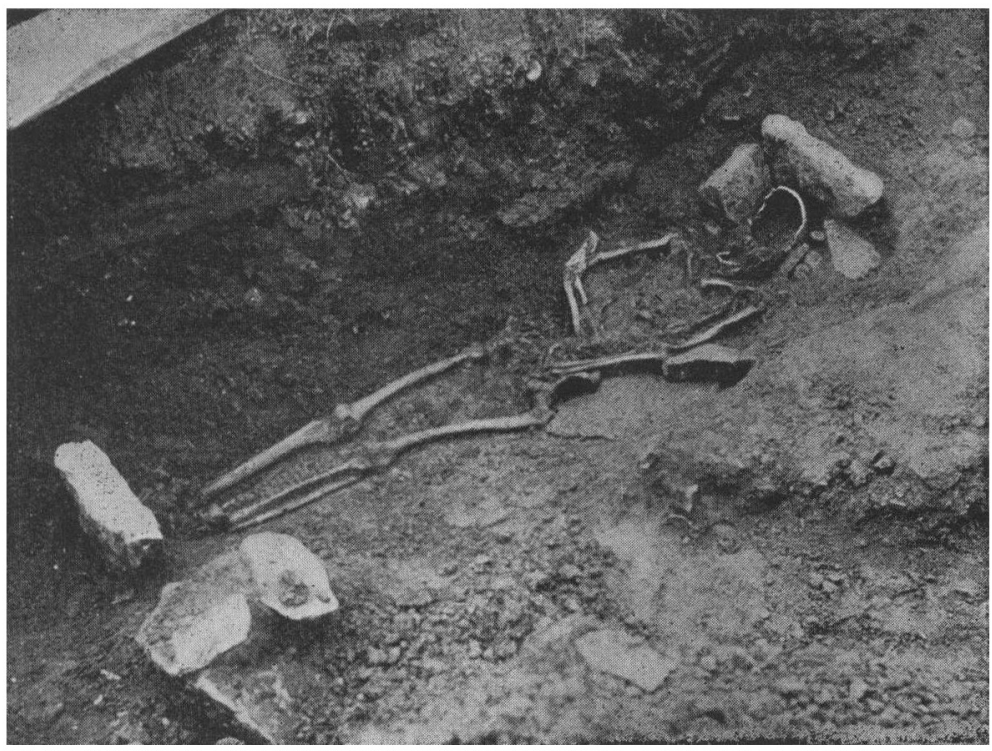

No. 2. ROMAN BUILDINGS NEAR CARDIFF: BURIAL IN ANNEXE (p. 78 ). 


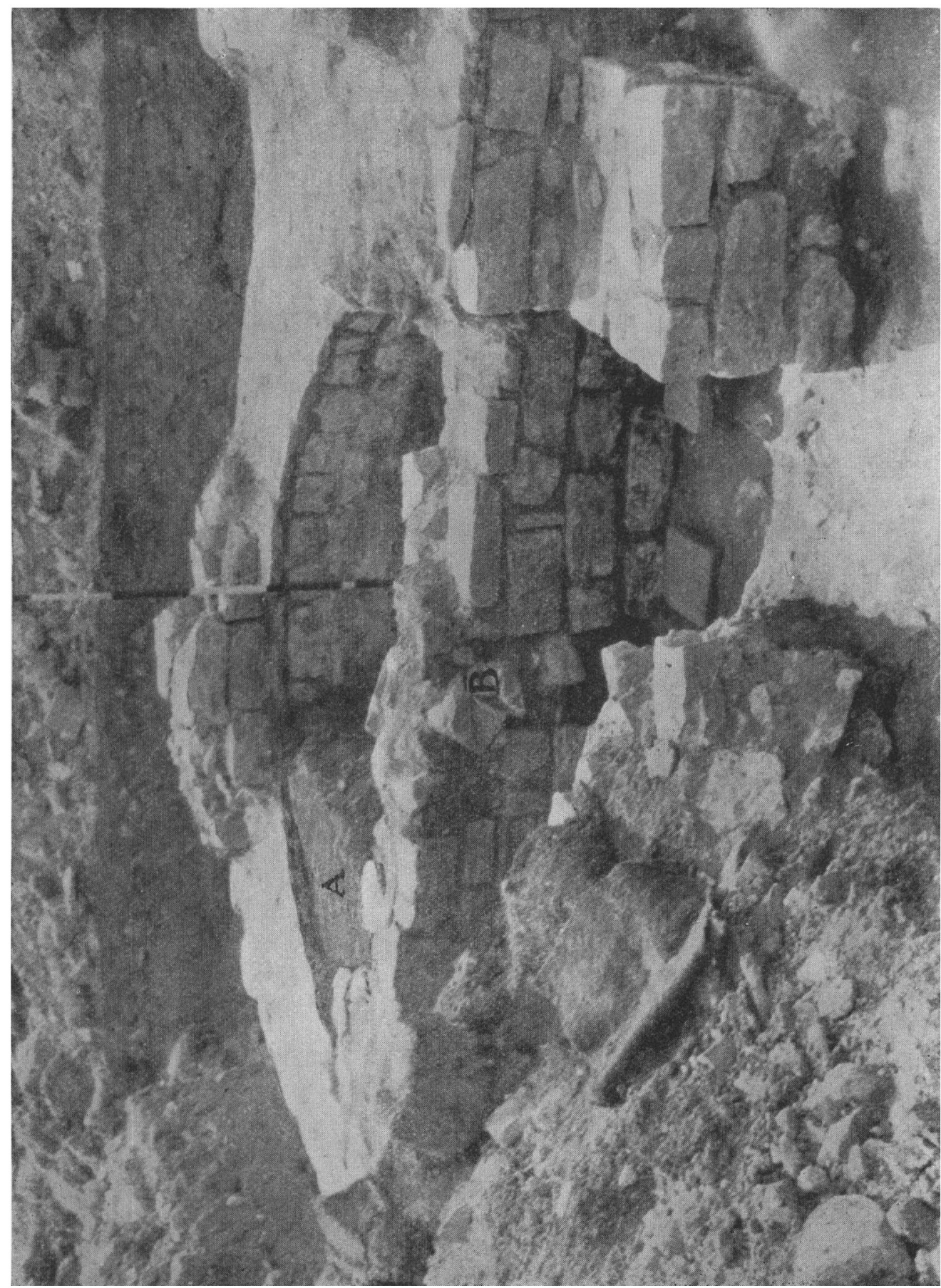

定 


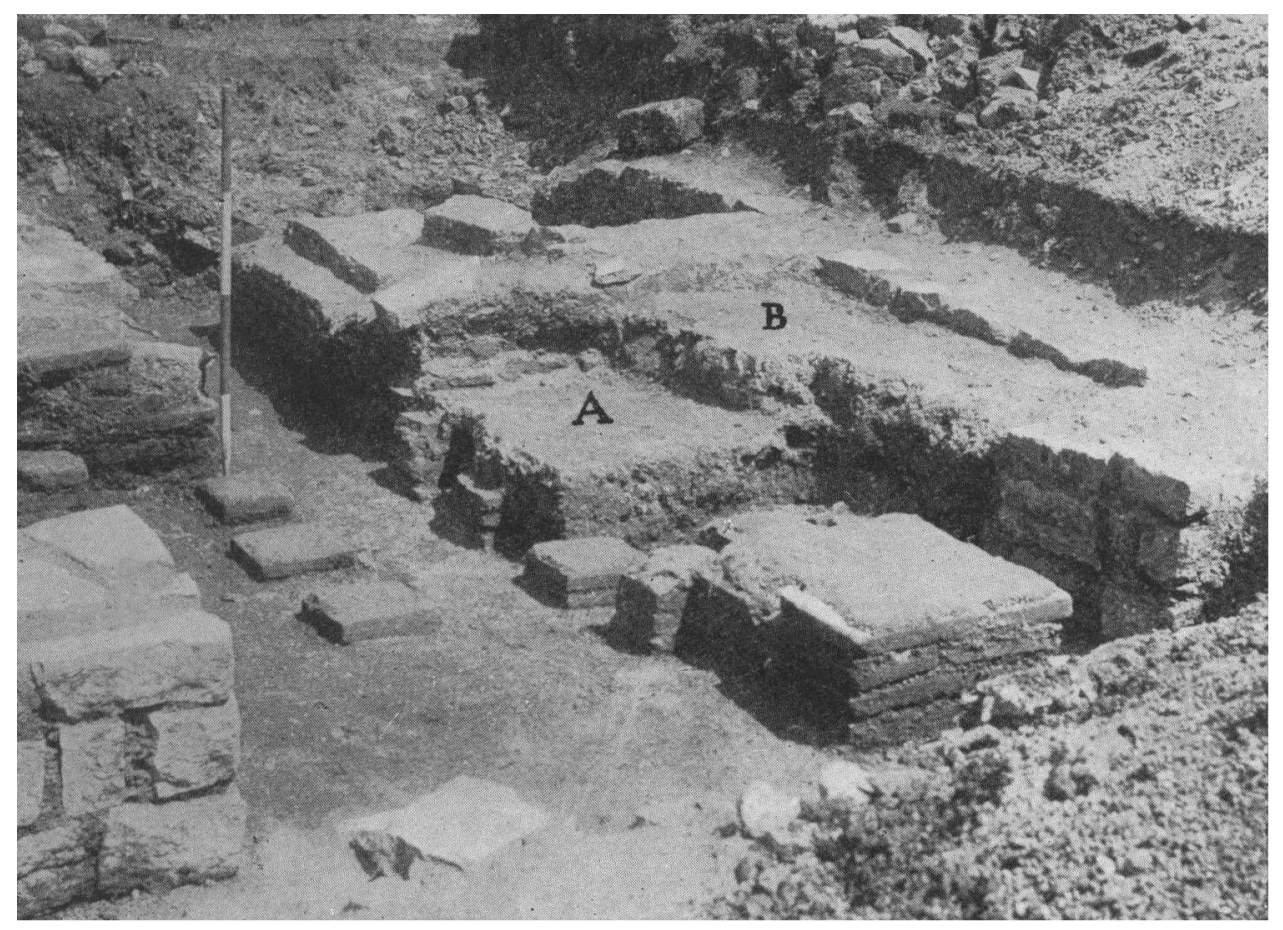

NO. I. ROMAN BUILDINGS NEAR CARDIFF : ROOM 2 I FROM S.W., SHOWING TWO SUCCESSIVE CEMENT FLOORS (A AND B) FILLING ORIGINAL HYPOCAUST (p. 75).

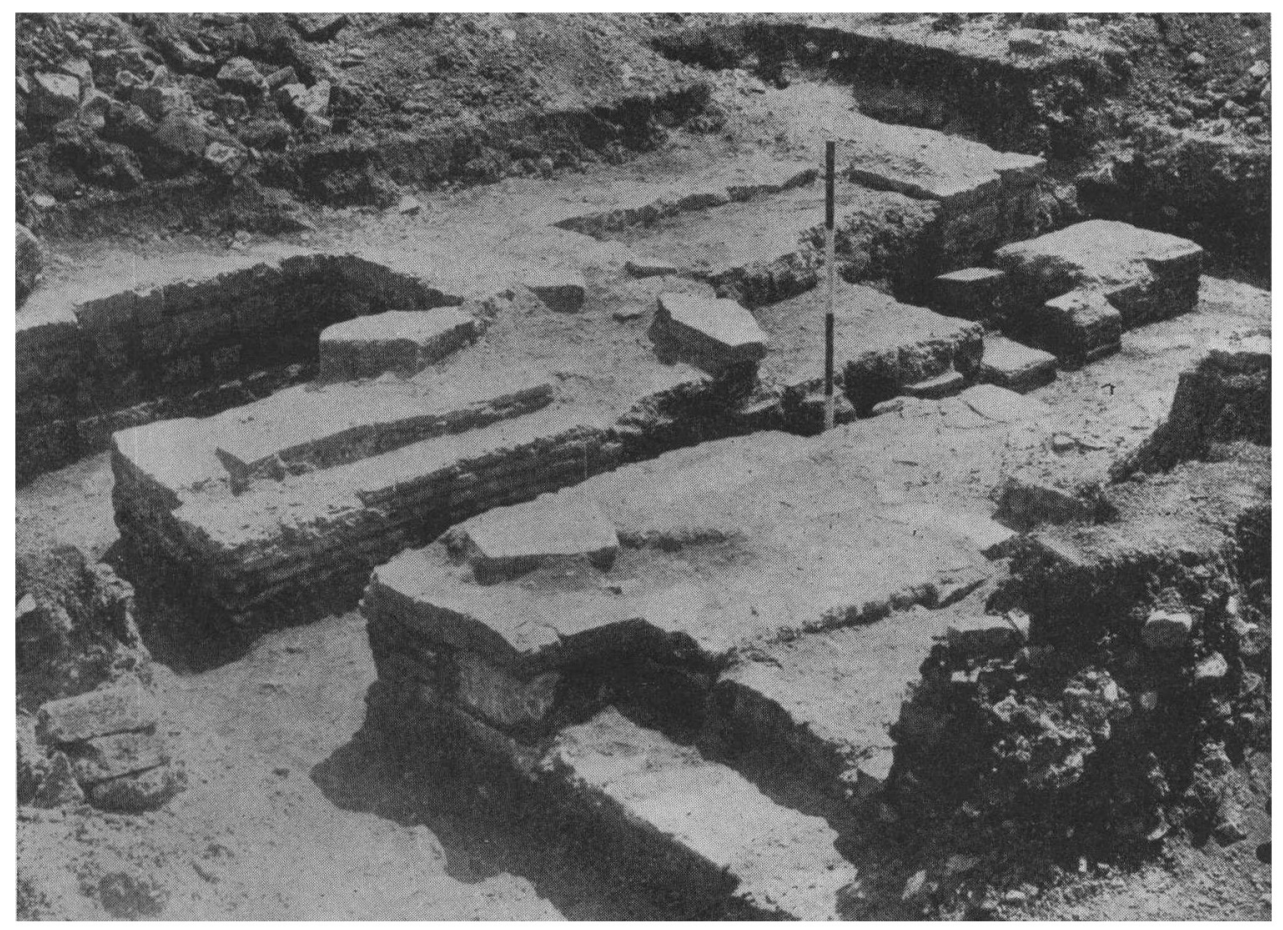

No. 2. ROMAN BUILDINGS NEAR CARDIFF : FURNACE OF BATHS AND ROOM 2 I FROM N.w. (p. 75). https://doi.org/10.2307/295887 Published online by Cambridge University Press 